\title{
Purification, Characterization, and Biodelignification Potential of Lignin Peroxidase from Immobilized Phanerochaete chrysosporium
}

\author{
Thammaiah Vandana, ${ }^{a}$ Samanta Ashish Kumar, ${ }^{\mathrm{b}}$ Senani Swaraj, ${ }^{\mathrm{b}}$ and Sridhar Manpal ${ }^{\mathrm{a}, *}$ \\ Lignin peroxidase (LiP), which has been studied extensively in white-rot \\ Basidiomycetes with regard to bio-pulping and bio-bleaching, plays a role in \\ the biodegradation of plant cell wall lignin. In the current study, LiP obtained \\ from a wild isolate of Phanerochaete chrysosporium immobilized on \\ polyurethane foam cubes was purified 21 -fold using ammonium sulphate \\ precipitation and size exclusion chromatography. The enzyme with a \\ molecular mass of $55 \mathrm{kDa}$ exhibited a considerably higher $\mathrm{pH}$ tolerance and \\ thermostability compared with the native enzyme. It showed a strong affinity \\ for the substrate veratryl alcohol and had kinetic constant values of 142.86 \\ $\mu \mathrm{mol}$ and $65 \mu \mathrm{M}$. Cysteine, sodium azide, mercaptoethanol, and silver nitrate \\ inhibited the activity, while ethanol, EDTA, $\mathrm{Cu}^{2+}, \mathrm{Mn}^{+}, \mathrm{Na}^{+}$, and $\mathrm{Fe}^{2+}$ \\ exhibited induction. Purified LiP completely decolorized (100\%) bromo \\ phenyl blue, bromothymol blue, and bromocresol green. The 96 and $72 \%$ \\ degradation obtained with phenol and congo red was also higher compared \\ to crude LiP. Treatment with LiP showed reduction in ADL as compared to \\ untreated straws, with a maximum of 2.87 units obtained in JR followed by \\ 2.66 units in PS. The digestibility of all straws increased, the response \\ varying from a maximum of 21.27 units in PRM to a minimum of 12.32 units \\ obtained in LM.
}

Keywords: Ligninolytic enzyme; Lignin peroxidase; Phanerochaete chrysosporium; Immobilization; Stability; Delignification; Ruminants

Contact information: a: Bioenergetics and Environmental Sciences Division, ICAR-National Institute of Animal Nutrition and Physiology, Adugodi, Bangalore, 560 030, Karnataka, India; b: Animal Nutrition Division, ICAR-National Institute of Animal Nutrition and Physiology, Adugodi, Bangalore, 560 030, Karnataka, India; *Corresponding author: manpalsridhar@yahoo.co.uk

\section{INTRODUCTION}

Lignin is considered to be the most abundant renewable raw material, other than cellulose, and it plays an important role in the carbon cycle of the biosphere (Schmidt 2006). It prevents microbial degradation of accessible carbohydrates within cell walls (Jeffries 1994). Because of their selective lignin degrading properties, the ligninolytic enzymes of white-rot fungi have immense potential in various biotechnological applications, including in the kraft pulping for the paper industry, wastewater treatment, bio leaching, ethanol production, denim stone washing, etc. The interest of the authors in ligninolytic enzymes focused on the deconstruction of lignin in lignocellulosic biomass for use as animal feed for ruminants (Rodrigues et al. 2008; Sharma and Arora 2010a,b; Sarnklong et al. 2010, 2011; Sridhar et al. 2015; van Kuijk et al. 2015). Ligninolytic enzyme systems consist mainly of manganese peroxidase, lignin peroxidase (LiP), and laccase. Some evidence has shown that many ligninolytic fungi use a combination of any two of these three enzymes (Kuwahara et al. 1984; Kantelinen et al. 1989). 
Lignin peroxidases (EC 1.11.1.14) play a central role in the biodegradation of plant cell wall lignin (Piontek et al. 2001). They belong to the family of oxidoreductases, first described in Phanerochaete chrysosporium (Glenn et al. 1983). Lignin peroxidase is an extracellular hemeprotein that is $\mathrm{H}_{2} \mathrm{O}_{2}$-dependent, with an unusually high redox potential and low optimum $\mathrm{pH}$. It is capable of oxidizing a variety of reducing substrates, including polymeric substrates (Schoemaker and Piontek 1996; Piontek et al. 2001). It has the distinction of being able to oxidize methoxylated aromatic rings without a free phenolic group, which generates cation radicals that can react further by a variety of pathways, including ring opening, demethylation, and phenol dimerization. In contrast with laccases, LiP does not require mediators to degrade high redox-potential compounds, but it needs $\mathrm{H}_{2} \mathrm{O}_{2}$ to initiate catalysis.

It has been observed that extracellular enzymes of white-rot fungi play an important role in the deconstruction of lignin in lignocellulosic biomass (Sridhar et al. 2015; Datta et al. 2017). Consequently, lignin degradation of crop residues by the laccases of Schizophyllum commune has been studied (Kumar et al. 2015).

Most studies on lignin biodegradation have been done with the white-rot fungus $P$. chrysosporium. Two ligninolytic peroxidases, LiP and manganese peroxidase, have been studied (Kirk and Farrell 1987). Though not well elucidated, LiP may also play a major role in the bio-delignification of lignocellulose in crop residues. Not all species of whiterot fungi secrete LiP. In the native state, white-rot fungi produce these enzymes in minute quantities that are sensitive to denaturing conditions typically found in the gut (anaerobic conditions, temperature, and $\mathrm{pH}$ ), which should be considered when enhancing the digestibility of crop residues for ruminants. Their potential for use in enhancing livestock productivity has stimulated the need to produce these enzymes with better stabilities in sufficiently large quantities in an economically viable manner.

Within the frame of the development of a bioprocess using the competencies of LiP to enhance the digestibility of crop residues, the present study was aimed at enhancing the production of LiP by a wild isolate of $P$. chrysosporium immobilized on polyurethane foam cubes (PUF) by submerged fermentation. The produced enzyme was purified and characterized. This is the first report on the purification and characterization of LiP obtained after immobilization of whole fungal cells. The potential of partially purified LiP in the deconstruction of lignin in crop residues was also evaluated in vitro. To the knowledge of the authors, there are no studies on enhancing the digestibility of crop residues by way of delignification with LiP produced from immobilized $P$. chrysosporium.

\section{EXPERIMENTAL}

\section{Materials and Methods}

Chemicals, reagents, and dyes

Substrates and bovine serum albumin (BSA) were purchased from Sigma Chemicals (St. Louis, USA), while all of the other chemicals and dyes were purchased from HiMedia (Mumbai, India). Finger millet (FMS), little millet (LM), bajra (BA), barnyard millet (BRM), paddy (PS), maize stover (MS), jowar (JR), foxtail millet (FXM), and prosomillet (PRM) straws were procured from a local market.

\section{Strain selection and enzyme production}

White-rot fungi were isolated from decaying wood from Western Ghats of Coorg, 
Karnataka, India. Basidiocarps (fruiting bodies) were inoculated into mycological agar slants and the tissue culture technique was employed for isolation (Revankar and Lele 2006). Two selected cultures were grown on $2 \%$ malt extract agar plates and maintained at $4{ }^{\circ} \mathrm{C}$. The isolates were screened for LiP production on potato dextrose agar, malt extract, and mycological agar for $7 \mathrm{~d}$ at $30{ }^{\circ} \mathrm{C}$. The isolate was morphologically identified as $P$. chrysosporium by the Microbial Type Culture Collection (Chandigarh, India) and was able to produce detectable levels of LiP enzyme. It was cultivated using submerged fermentation to immobilize the fungus on PUF cubes after pretreatment (Prasad et al. 2005). The medium contained $30 \mathrm{~g} / \mathrm{L}$ malt extract, $5.0 \mathrm{~g} / \mathrm{L}$ peptone, and $15.0 \mathrm{~g} / \mathrm{L}$ agar, and was supplemented with penicillin and streptomycin to prevent bacterial contamination. The flasks were inoculated with $0.6 \mathrm{~mL}$ of the homogenized mycelia under aseptic conditions after sterilization and incubated at room temperature $\left(28{ }^{\circ} \mathrm{C} \pm 4{ }^{\circ} \mathrm{C}\right)$ under continuous shaking on an orbital shaker $(120 \mathrm{rpm})$. The growth medium was removed and replenished with Kirk's basal medium, which contained $0.22 \mathrm{~g} / \mathrm{L}$ ammonium tartrate, $0.2 \mathrm{~g} / \mathrm{L}$ potassium di-hydrogen phosphate, $0.05 \mathrm{~g} / \mathrm{L}$ magnesium sulphate heptahydrate, $0.01 \mathrm{~g} / \mathrm{L}$ calcium chloride, $1 \mathrm{mg} / \mathrm{L}$ thiamine, $10 \mathrm{~mL} / \mathrm{L}$ Tween $(10 \%), 1.5 \mathrm{mM}$ veratryl alcohol, $10 \mathrm{~mL} / \mathrm{L}$ trace element solution, and $5 \mathrm{~g} / \mathrm{L}$ glucose. The $\mathrm{pH}$ of the solution was adjusted to 3.5 , and the cultures were incubated at room temperature $\left(28^{\circ} \mathrm{C} \pm 4{ }^{\circ} \mathrm{C}\right)$ on a rotary shaker $(120 \mathrm{rpm})$ for $25 \mathrm{~d}$ with five replicates. The LiP activity was monitored regularly.

\section{LiP assay}

The LiP activity was assayed spectrophotometrically (Shimadzu UV 1800 spectrophotometer, Kyoto, Japan) by measuring the rate of $\mathrm{H}_{2} \mathrm{O}_{2}$-dependent oxidation of veratryl alcohol to veratraldehyde (Tien and Kirk 1988), as well as by the Dye B Azure method (Arora and Gill 2001). The veratryl alcohol assay contained $0.8 \mathrm{mM}$ veratryl alcohol in $0.1 \mathrm{M}$ sodium tartrate buffer $(\mathrm{pH}=3.0)$. To this, $1 \mathrm{~mL}$ of culture filtrate buffer was added in the presence of $150 \mathrm{mM} \mathrm{H}_{2} \mathrm{O}_{2}$. The linear absorbance was read at $310 \mathrm{~nm}$ for $1 \mathrm{~min}$ at $30^{\circ} \mathrm{C}$. One unit of LiP activity was defined as $1 \mu \mathrm{mol}$ veratraldehyde formed $/ \mathrm{min}$ and was expressed as $\mathrm{U} / \mathrm{mL}$ (molar extinction coefficient, $E_{\max }=9300 \mathrm{M}^{-1} \cdot \mathrm{cm}^{-1}$ ).

\section{Determination of the protein}

The protein concentration was determined by the method of Lowry et al. (1951) using BSA as a standard. The protein of the fractions collected by column chromatography (Wipro GE Healthcare Pvt Ltd, Bangalore, India) was estimated by reading the absorbance at $280 \mathrm{~nm}$.

\section{LiP purification and electrophoretic analysis}

All of the procedures were performed at $4{ }^{\circ} \mathrm{C}$, unless otherwise stated. The culture media from the culture flasks were harvested on day 10. Solids were precipitated using $65 \%$ saturated $\left(\mathrm{NH}_{4}\right)_{2} \mathrm{SO}_{4}$ and centrifugation at $10600 \mathrm{~g}$ for $15 \mathrm{~min}$ at $4{ }^{\circ} \mathrm{C}$. The precipitate was dissolved in $100 \mathrm{~mL}$ of distilled water and dialyzed overnight against $100 \mathrm{~mL}$ of 0.5 $\mathrm{M}$ sodium tartrate buffer with a $\mathrm{pH}$ of 3.5 at $4{ }^{\circ} \mathrm{C}$ using dialysis tubing with a molecular weight cut off of approximately $8000 \mathrm{Da}$. It was loaded onto a $44 \mathrm{~cm} \times 3.0 \mathrm{~cm}$ Sephadex G75 column (Sigma Aldrich Chemicals Pvt Ltd Bangalore, India) pre-equilibrated with 0.5 $\mathrm{M}$ sodium tartrate buffer $(\mathrm{pH}=3.5)$ and eluted with the same buffer. Five-milliliter fractions were collected at a flow rate of $1 \mathrm{~mL} / \mathrm{min}$. The collected fractions were assayed for both protein and LiP enzyme activity. The active fractions were pooled and 
concentrated on an Amicon PM 10 membrane (Merck Millipore, Darmstadt, Germany) and stored at $-20{ }^{\circ} \mathrm{C}$.

Sodium dodecyl sulfate polyacrylamide gel electrophoresis (SDS-PAGE) (Laemmli 1970) was performed using $12.5 \%$ separating gel and 4\% stacking gel at room temperature with a precision plus protein standard (Bio-Rad Laboratories India Pvt. Ltd., Gurugram, Haryana, India). The enzyme sample was boiled for $10 \mathrm{~min}$ and centrifuged at $2000 \mathrm{rpm}$ for $10 \mathrm{~min}$. The gel was run at 60/80 V until the dye reached the end of the separating gel. Staining of the protein bands was done using Coomassie Brilliant Blue R250 , which was followed by fixing and de-staining.

\section{Biochemical characterization of the partially purified LiP}

The properties and kinetics of the purified LiP obtained through immobilization of P. chrysosporium on PUF cubes were studied.

\section{Effect of the $p H$}

The LiP activity was assayed using $100 \mathrm{mM}$ veratryl alcohol at different $\mathrm{pH}$ values ranging from 3 to 10 with an interval of 0.5 using appropriate buffers. The buffers included sodium phosphate citric acid buffer with a $\mathrm{pH}$ of 5 to 6.5 , sodium phosphate buffer with a $\mathrm{pH}$ of 7 to 8.5 , sodium tartrate buffer with a $\mathrm{pH}$ of 3 to 4.5 , and carbonate buffer with a $\mathrm{pH}$ of 9 to 10 , all of which were prepared at a concentration of $0.5 \mathrm{M}$. The $\mathrm{pH}$ stability of the purified LiP was determined by exposing the enzyme to $\mathrm{pH}$ values ranging from 3 to 10 with an interval of 0.5 and estimating the activity after $30 \mathrm{~s}$ and $15 \mathrm{~min}$.

\section{Effect of the temperature on the LiP activity}

Lignin peroxidase was incubated with $100 \mathrm{mM}$ veratryl alcohol in $0.5 \mathrm{M}$ sodium tartrate buffer with a $\mathrm{pH}$ of 5.5. The temperature ranged from $25{ }^{\circ} \mathrm{C}$ to $40{ }^{\circ} \mathrm{C}$ with an interval of $0.5^{\circ} \mathrm{C}$, and the optimum temperature was determined. Furthermore, the enzyme was incubated for various time intervals ranging from $0 \mathrm{~min}$ to $10 \mathrm{~min}$ with 2-min intervals at temperatures ranging from $25^{\circ} \mathrm{C}$ to $85^{\circ} \mathrm{C}$ with an interval of $10^{\circ} \mathrm{C}$ to examine the effect of the incubation temperature on the enzyme activity. The thermostability of the enzyme was determined by incubating the enzyme at $60{ }^{\circ} \mathrm{C}, 65^{\circ} \mathrm{C}, 70{ }^{\circ} \mathrm{C}, 75^{\circ} \mathrm{C}$, and $80{ }^{\circ} \mathrm{C}$ for periods ranging from $20 \mathrm{~min}$ to $120 \mathrm{~min}$ with an interval of $20 \mathrm{~min}$. The tubes were then immediately cooled in an ice bath and the activity was determined.

\section{Effect of various activators and inhibitors on the LiP activity}

The stimulatory/inhibitory effects of different organic compounds (EDTA, Cysteine, ethanol, sodium azide, mercaptoethanol, and silver nitrate) on the LiP activity were investigated. These compounds were added at concentrations of $10^{-3} \mathrm{M}$ and $10^{-4} \mathrm{M}$, and the residual activity was determined after $10 \mathrm{~min}$ of incubation. The activity of the purified LiP in the presence of only veratryl alcohol was taken as $100 \%$.

Different metal ions $\left(\mathrm{Cu}^{2+}, \mathrm{Fe}^{2+}, \mathrm{Mn}^{+}, \mathrm{Na}^{+}, \mathrm{Zn}^{+}, \mathrm{Mg}^{2+}, \mathrm{Ca}^{2+}\right.$, and $\left.\mathrm{Ag}^{+}\right)$were evaluated in a similar fashion by incubating the enzyme with a metal ion for $10 \mathrm{~min}$ at concentrations of $10^{-3} \mathrm{M}$ and $10^{-4} \mathrm{M}$. The activity of the purified LiP in the presence of only veratryl alcohol was taken as $100 \%$.

\section{Effect of various substrates on the LiP}

Several compounds were tested as potential LiP substrates at a concentration of 100 $\mathrm{mM}$ and the list of substrates (mediator compounds) tested is given in Table 1. The rate of 
substrate oxidation was measured by determining the increase in the absorbance at their respective wavelengths.

Table 1. List of Compounds Tested as Potential Substrates for LiP

\begin{tabular}{|c|c|c|}
\hline Substrate & $\boldsymbol{E}_{\max }\left(\mathbf{M}^{\mathbf{- 1}} \cdot \mathbf{c m}^{-\mathbf{1}}\right)$ & Wavelength $\mathbf{( n m})$ \\
\hline Veratryl alcohol & 9300 & 310 \\
\hline Guaiacol & 6400 & 436 \\
\hline Catechol & 2211 & 392 \\
\hline Butyl alcohol & - & 310 \\
\hline Vanillic acid & - & 390 \\
\hline Amyl alcohol & - & 310 \\
\hline Pyrogallol & 2490 & 450 \\
\hline
\end{tabular}

\section{Determination of the kinetic constants}

Various concentrations of veratryl alcohol $(0 \mathrm{mM}$ to $140 \mathrm{mM})$ as the substrate were used to determine the values of the kinetic constants $K_{\mathrm{m}}$ and $V_{\max }$ of the LiP from $P$. chrysosporium at a $\mathrm{pH}$ of 3.5 using sodium tartrate buffer $(0.5 \mathrm{M})$. All of the reactions were performed at $30{ }^{\circ} \mathrm{C}$. The $E_{\max }$ for veratryl alcohol was found to be $9300 \mathrm{M}^{-1} \cdot \mathrm{cm}^{-1}$. A Lineweaver-Burk plot was plotted between the inverse of the substrate concentration and velocity of the reaction to determine the $K_{\mathrm{m}}$ and $V_{\max }$ of the enzyme $\left(1 / v=K_{\mathrm{m}} / V_{\max } \times 1 / S\right.$ $\left.+1 / V_{\max }\right)$.

\section{Decolorization extent assays}

The decolorizing ability of the LiP was evaluated with five dyes, e.g., Tetrabromophenol Blue or 3,3',5,5'-tetrabromophenolsulfonphthalein (bromophenol blue) (industrial dye); 3',3"-Dibromo thymol sulfonephthalein (bromothymol blue); Bromo cresol green (triphenylmethane dye); Congo red (diazo dye); and Phenol sulfonephthalein (phenol red or PSP). The reaction mixture consisted of $0.890 \mathrm{~mL}$ of $0.2 \mathrm{M}$ citrate/phosphate buffer with a $\mathrm{pH}$ of $4.0,0.1 \mathrm{~mL}$ of each dye at $1 \%$ final concentrations, and $0.01 \mathrm{~mL}$ of pure $\mathrm{LiP}$ (final concentration of $5 \mathrm{U} / \mathrm{mL}$ ). Assays were performed at $25^{\circ} \mathrm{C}$ and the reaction was initiated with the addition of the enzyme. After incubation for $30 \mathrm{~min}$, decolorization of the dye was monitored at the maximum visible absorbance. The results were expressed as the percent of remaining color as a function of the incubation time, according to the following relationship,

$$
\text { Remaining Color }(\%)=(\text { Abs final } / \text { Abs initial }) \times 100 \%
$$

where Abs final is the absorbance value at the indicated incubation time and Abs initial is the initial absorbance value.

To exclude the possibility that decolorization of the dyes occurred because of nonbiological oxidation, the dyes were incubated with $150 \mathrm{mM} \mathrm{H}_{2} \mathrm{O}_{2}$ in the absence of the enzyme. None of the dyes showed any change in absorption after $30 \mathrm{~min}$ of incubation.

\section{Deconstruction of lignin in the crop residues and in vitro incubation}

The LiPs obtained after immobilization to enhance production (T1) and after purification (T2) were used in the study. The FMS, LM, BA, BRM, PS, MS, JR, FXM, and PRM were procured from a local market, manually chaffed to a 2-cm length, and treated by spraying with LiP enzyme extracts of both T1 and T2 at an enzyme to straw ratio of 1:2.5 (Sridhar et al. 2015). Untreated straws served as controls. The straws were left 
overnight for treatment, dried at $60{ }^{\circ} \mathrm{C}$, ground to pass through a $1-\mathrm{mm}$ screen, and then analyzed. The dry matter of the untreated and treated dried samples was determined at $100{ }^{\circ} \mathrm{C} \pm 5^{\circ} \mathrm{C}$ after $8 \mathrm{~h}$. The nitrogen $(\mathrm{N})$ content was determined by the standard Kjeldahl method (AOAC 2005), and the crude protein content was calculated $(\mathrm{N} \times 6.25)$. The ash content was determined using a muffle furnace. The neutral detergent fiber (NDF), acid detergent fiber (ADF), and acid detergent lignin (ADL) contents were determined (Van Soest et al. 1991). The hemicellulose content of each sample was calculated as the difference between the NDF and ADF contents, while the cellulose content was calculated as the difference between the ADF and lignin contents. The in vitro dry matter digestibility (IVDMD) was determined according to Tilley and Terry (1963) and as described by Goering and Van Soest (1970). Each sample was run with five replicates.

\section{Statistical analysis}

All of the experiments were performed with three replicates. A proximate analysis was evaluated using PROC GLM in SAS 9.3 software (SAS Institute Inc., Cary, NC, USA). Significant differences between the treatments were determined using the t-test at an $\alpha$ value of 0.05 .

\section{RESULTS AND DISCUSSION}

\section{Strain Selection, Immobilization, and Enzyme Production}

Phanerochaete chrysosporium is a wood-rotting basidiomycete and dominant LiP enzyme synthesizer. Differences in titers of enzyme yielded by organisms in different studies could have been because of the different inherent capacities of the organisms to synthesize ligninolytic enzymes, growth conditions, nutritional requirements, and inducers (Niku-Paavola et al. 1990; Rogalski et al. 1991; Schlosser et al. 1997).

Though LiPs are the most investigated ligninolytic enzymes, this study characterized the enzyme produced by immobilized Phanerochaete sp. The wild isolate of $P$. chrysosporium (LPS1) was confirmed to be strongly positive for LiP production in both the plate screening tests (Fig. 1) and submerged culture. Reports are available on enhancing the secondary metabolite production using the immobilized approach (Nakamura et al. 1997; de Ory et al. 2004). A variety of matrices, such as agar carrageenan, calcium alginate gels, polyacrylamide, etc., have been used, but the nature of the cell to be immobilized, nature of the substrates and products formed, and culture conditions are major factors to consider when choosing the matrix and immobilization procedure. Adsorption to surfaces and encapsulation within gels or porous materials (a particular type of physical entrapment) have been the most widely studied methods for the immobilization of microbes. These techniques represent a particular form of cellular adhesion based on the ability of certain microorganisms to fix themselves to solid surfaces by means of the secretion of polymucosaccharides (Moonmangmee et al. 2002). Of the various matrices tested for the immobilization of fungi for ligninolytic enzyme production, PUF proved to be the ideal synthetic matrix, according to the 10-fold increase in the activity, which was in agreement with Nakamura et al. (1997). The $P$. chrysosporium (LPS1) culture immobilized on PUF cubes secreted the highest LiP levels in the submerged culture between days 6 and 8 , and thus was selected for further study (Fig. 2). 


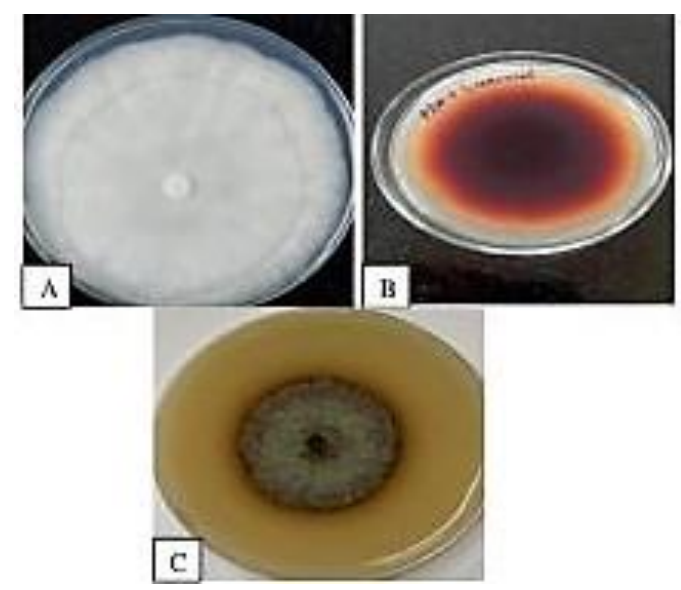

Fig. 1. (A) White-rot fungi; (B) a reddish-brown color formed around the colonies because of guaiacol; and $(C)$ screening with 2,3-dimethoxybenzidine $(0.1 \%)$ (confirmation test for LiP)

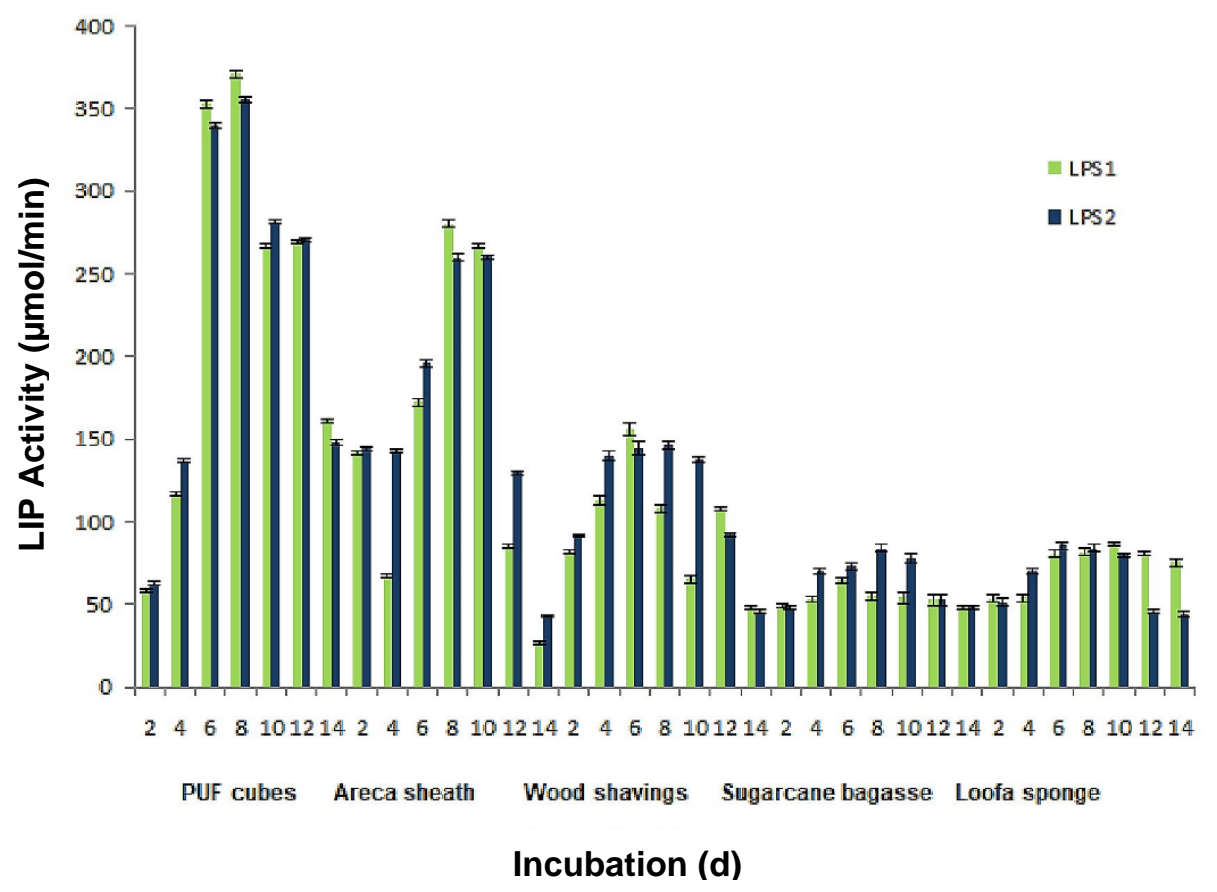

Fig. 2. Production of LiP in the submerged culture from P. chrysosporium immobilized on different matrices

\section{LiP Purification and Biochemical Characterization}

Sugiura et al. (2003) cultivated a novel LiP from the white-rot fungus $P$. sordida YK-624 in a Mn-deficient nitrogen-limited media for $7 \mathrm{~d}$, and it was purified to homogeneity by anion-exchange chromatography and gel-permeation chromatography. It showed a 7.4-fold increase with a yield of 144\%. Asgher et al. (2012) isolated LiP from an indigenous Trametes versicolor IBL-04 strain cultured in a solid-state fermentation medium of corn cobs, and a maximum LiP activity of $592 \mathrm{U} / \mathrm{mL} \pm 6 \mathrm{U} / \mathrm{mL}$ was reported after $5 \mathrm{~d}$ of incubation under the optimum culture conditions. The crude LiP was purified 3.3 -fold with a specific activity of $553 \mathrm{U} / \mathrm{mg}$ after passing through the chromatography columns. The purified LiP exhibited a relatively low molecular weight $(30 \mathrm{kDa})$ 
homogenous single band in native and SDS-PAGE. Yang et al. (2005) purified and characterized LiP from a liquid culture of Penicillium decumbens P6, a lignite-degrading fungus, using $\left(\mathrm{NH}_{4}\right)_{2} \mathrm{SO}_{4}$ precipitation, ion-exchange chromatography on DEAE-cellulose and CM-cellulose, gel filtration, and non-denaturing discontinuous PAGE. The enzyme had a molecular weight of $46.3 \mathrm{kDa}$ in SDS-PAGE.

Lignin peroxidases are heme-containing glycoproteins, and the subunit molecular weight of white-rot fungal LiP is reported to range between $38 \mathrm{kDa}$ and $48 \mathrm{kDa}$ (Fakoussa and Hofrichter 1999; Sugiura et al. 2003; Yang et al. 2005; Arora et al. 2011). Employing gel filtration, LiP was eluted as one major peak (Fig. 3) in the current study and was purified 21 -fold with a yield of $69 \%$ (Table 2). The results of the SDS-PAGE showed that the LiP obtained from the immobilized $P$. chrysosporium was a homogenous monomeric protein, which was evident by the single homogenous band corresponding to $55 \mathrm{kDa}$ (Fig. 4). This was higher than for the standard LiP, which showed a molecular weight of $48 \mathrm{kDa}$. The findings in the present study suggested that higher molecular mass enzymes are produced upon fungi immobilization compared with those produced in a submerged culture/solidstate culture and are in keeping with earlier studies with laccase (Kumar et al. 2015).

Table 2. Purification of the LiP obtained from the Immobilized P. chrysosporium

\begin{tabular}{|c|c|c|c|c|c|c|}
\hline $\begin{array}{c}\text { Purification } \\
\text { Step }\end{array}$ & $\begin{array}{c}\text { Total } \\
\text { Volume } \\
(\mathbf{m L})\end{array}$ & $\begin{array}{c}\text { Total LiP } \\
\text { Activity } \\
(\mathbf{U})\end{array}$ & $\begin{array}{c}\text { Total } \\
\text { Protein } \\
(\mathbf{m g})\end{array}$ & $\begin{array}{c}\text { Specific } \\
\text { Activity } \\
(\mathbf{U} / \mathbf{m g})\end{array}$ & $\begin{array}{c}\text { Yield } \\
(\%)\end{array}$ & $\begin{array}{c}\text { Purification } \\
\text { Fold }\end{array}$ \\
\hline Crude extract & 1400 & 322.58 & 856.8 & 0.376 & 100 & 1.0 \\
\hline $\begin{array}{c}\text { Ammonium } \\
\text { sulphate } \\
\text { precipitation }\end{array}$ & 100 & 280.65 & 72.1 & 3.892 & 87.00 & 10.35 \\
\hline Ultrafiltration & $82 \pm 4.99$ & 268.81 & 61.91 & 4.341 & 83.31 & 11.54 \\
\hline $\begin{array}{c}\text { Sephadex G- } \\
75\end{array}$ & $75 \pm 5.0$ & 221.50 & 60.9 & 7.896 & 68.66 & 21.0 \\
\hline
\end{tabular}

One unit of LiP activity was defined as $1 \mu \mathrm{mol}$ of veratraldehyde formed/min.

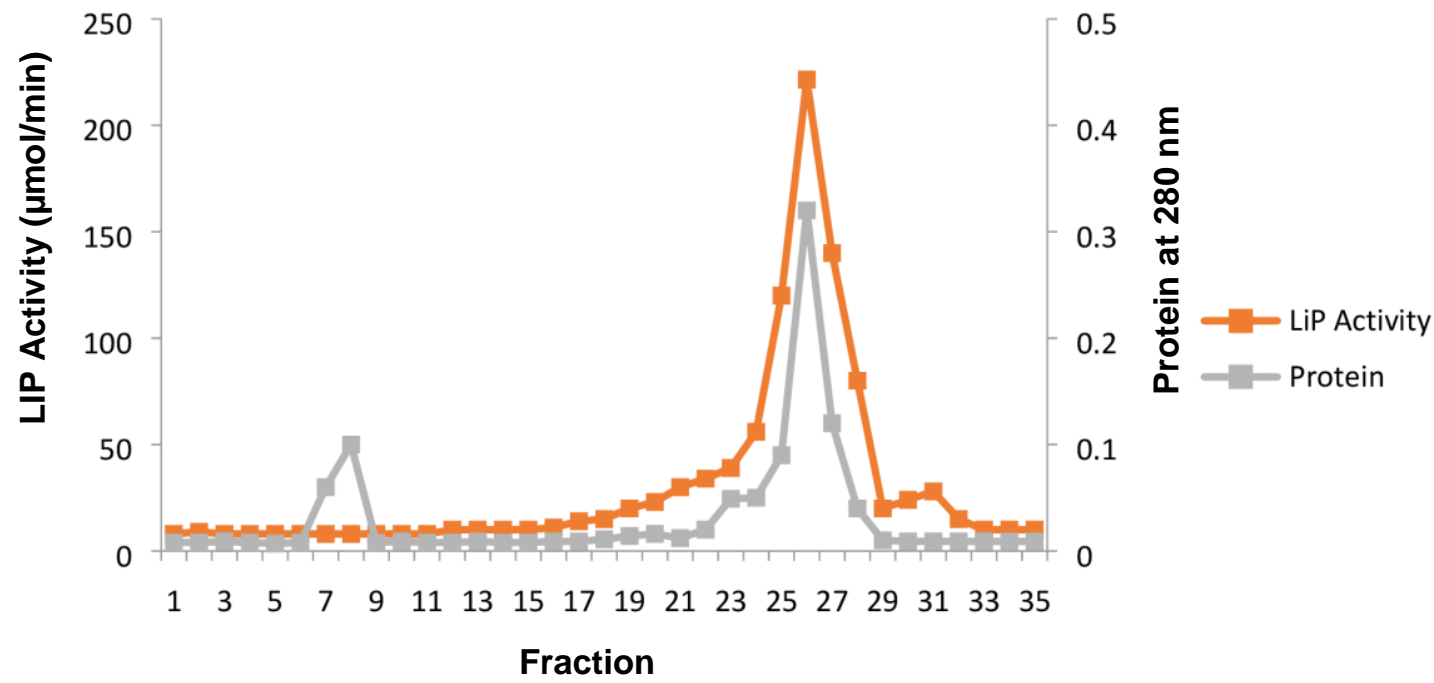

Fig. 3. Elution profile of the LiP upon gel filtration 


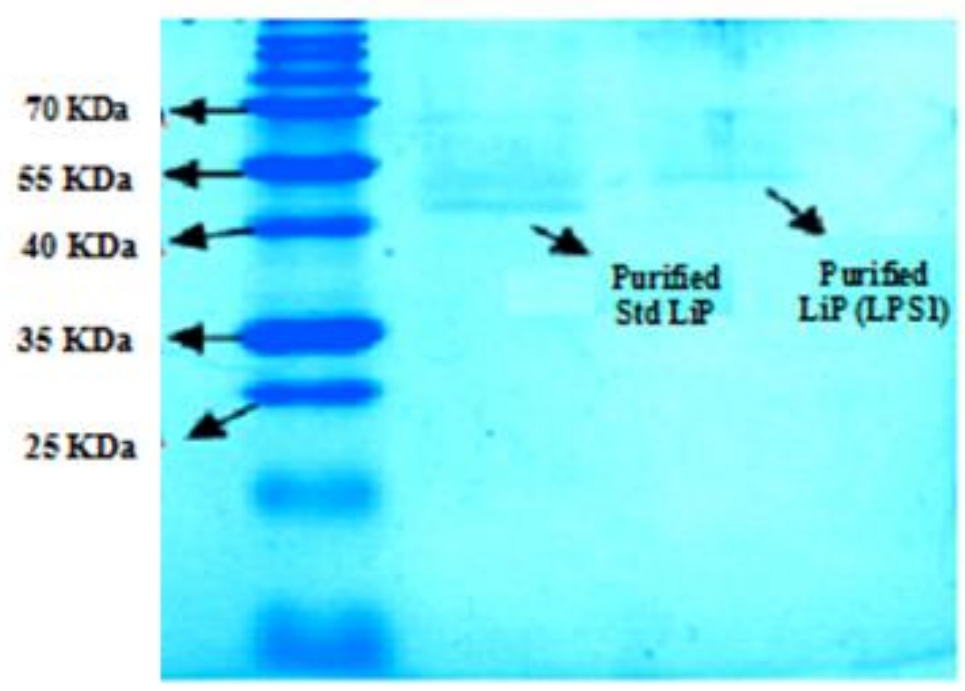

Fig. 4. SDS-PAGE results: lane 1 - molecular weight markers; lane 2 - purified standard LiP; and lane 3 - purified LiP obtained by immobilization of $P$. chrysosporium on PUF cubes

\section{Effect of the pH on the LiP Activity}

Phanerochaete chrysosporium enzymes show a higher stability at a $\mathrm{pH}$ of 3 to 3.5 and $30{ }^{\circ} \mathrm{C}$, and are still stable in the $\mathrm{pH}$ range of 5 to 6 . They modify kraft lignin and phenolic compounds containing hydroxy and methoxy groups. With veratryl alcohol as the substrate, LiP exhibits an optimum catalytic $\mathrm{pH}$ in the acidic range (Niku-Paavola et al. 1988). Asgher et al. (2012) showed LiP from Schizophyllum commune to be optimally active at a $\mathrm{pH}$ of 5 and $35^{\circ} \mathrm{C}$. Fakoussa and Hofrichter (1999) reported the $\mathrm{pH}$ range for LiP to be between 2.0 and 5.0, with an optimum between 2.5 and 3.0.

In this study, the purified LiP obtained through immobilization had an optimum $\mathrm{pH}$ of 5.5 with veratryl alcohol as the substrate (Fig. 5A). The enzyme exhibited an enhanced $\mathrm{pH}$ stability compared with the native enzyme obtained in the submerged cultures. It retained over $75 \%$ of the activity at a $\mathrm{pH}$ of 6.5 for over $15 \mathrm{~min}$ (Fig. 5B). This showed that it was superior to the purified LiP obtained from a liquid culture of Penicillium decumbens P6 (Yang et al. 2005), which exhibited an optimum $\mathrm{pH}$ of 4.0 , with $70.6 \%$ of the relative activity remaining at a $\mathrm{pH}$ of 9.0 .
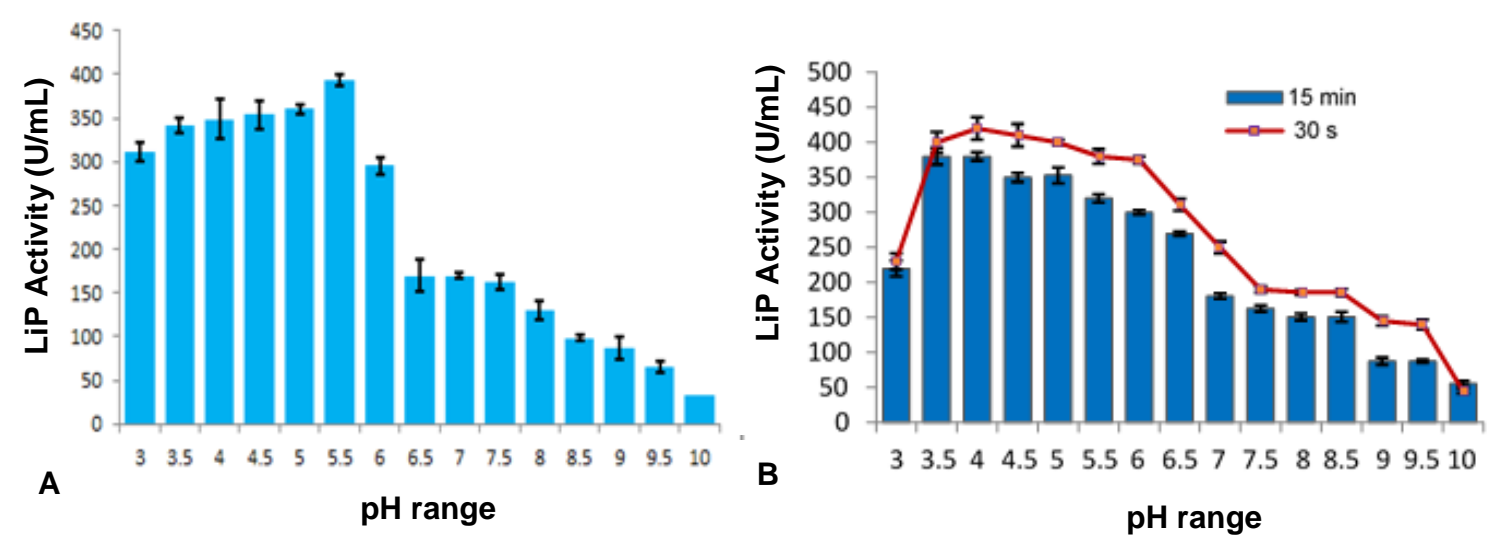

Fig. 5. (A) pH optima and stability of the purified LiP; and (B) $\mathrm{pH}$ stability of the purified laccase after $15 \mathrm{~min}$ (columns) and $30 \mathrm{~s}$ (curve) of incubation 


\section{Effect of the Temperature on the LiP Activity}

Lignin peroxidase from different white-rot fungi show optimum activities in the temperature range of $35^{\circ} \mathrm{C}$ to $60{ }^{\circ} \mathrm{C}$. Lignin peroxidase from Guanidium lucidium shows thermal stability at $25^{\circ} \mathrm{C}$ and the ligninolytic activity decreases as the temperature further increases (Hariharan and Nambison 2013). Lignin peroxidase from a liquid culture of Penicillium decumbens $\mathrm{P} 6$ has an optimum temperature of $45^{\circ} \mathrm{C}$ (Yang et al. 2005), but is not stable at higher temperatures.

The LiP obtained in a submerged culture through immobilized $P$. chrysosporium had an optimum activity at a temperature of $30^{\circ} \mathrm{C}$ (Fig. 6A). The purified enzyme exhibited a higher thermostability and retained over $50 \%$ of the activity, even after 120 min of incubation at both $60{ }^{\circ} \mathrm{C}$ and $65^{\circ} \mathrm{C}$. At $70{ }^{\circ} \mathrm{C}$, there was a loss of $25 \%$ of the activitiy at the end of 120 min of incubation. Only $25 \%$ of the activity was maintained after 100 min of incubation at both $75^{\circ} \mathrm{C}$ and $80{ }^{\circ} \mathrm{C}$, and the activity was completely lost at the end of 120 min (Fig. 6B). Purified LiP exhibited superior thermostability (Fig. 6 C), evaluated by incubating the enzyme at temperatures ranging between $25^{\circ} \mathrm{C}$ to as high as $80{ }^{\circ} \mathrm{C}$, with a maximum exposure of $10 \mathrm{~min}$. at each temperature, and enzyme activity measured at every two min. intervals. Purified LiP failed to reflect loss in activity at temperatures of up to $60{ }^{\circ} \mathrm{C}$ even up to $10 \mathrm{~min}$. after exposure. A drastic loss in activity of over $50 \%$ was evident upon exposure of the enzyme to temperatures of $70{ }^{\circ} \mathrm{C}$ and $80{ }^{\circ} \mathrm{C}$, with only 50 units of residual activity being obtained after 8 and $10 \mathrm{~min}$. at the latter temperature.
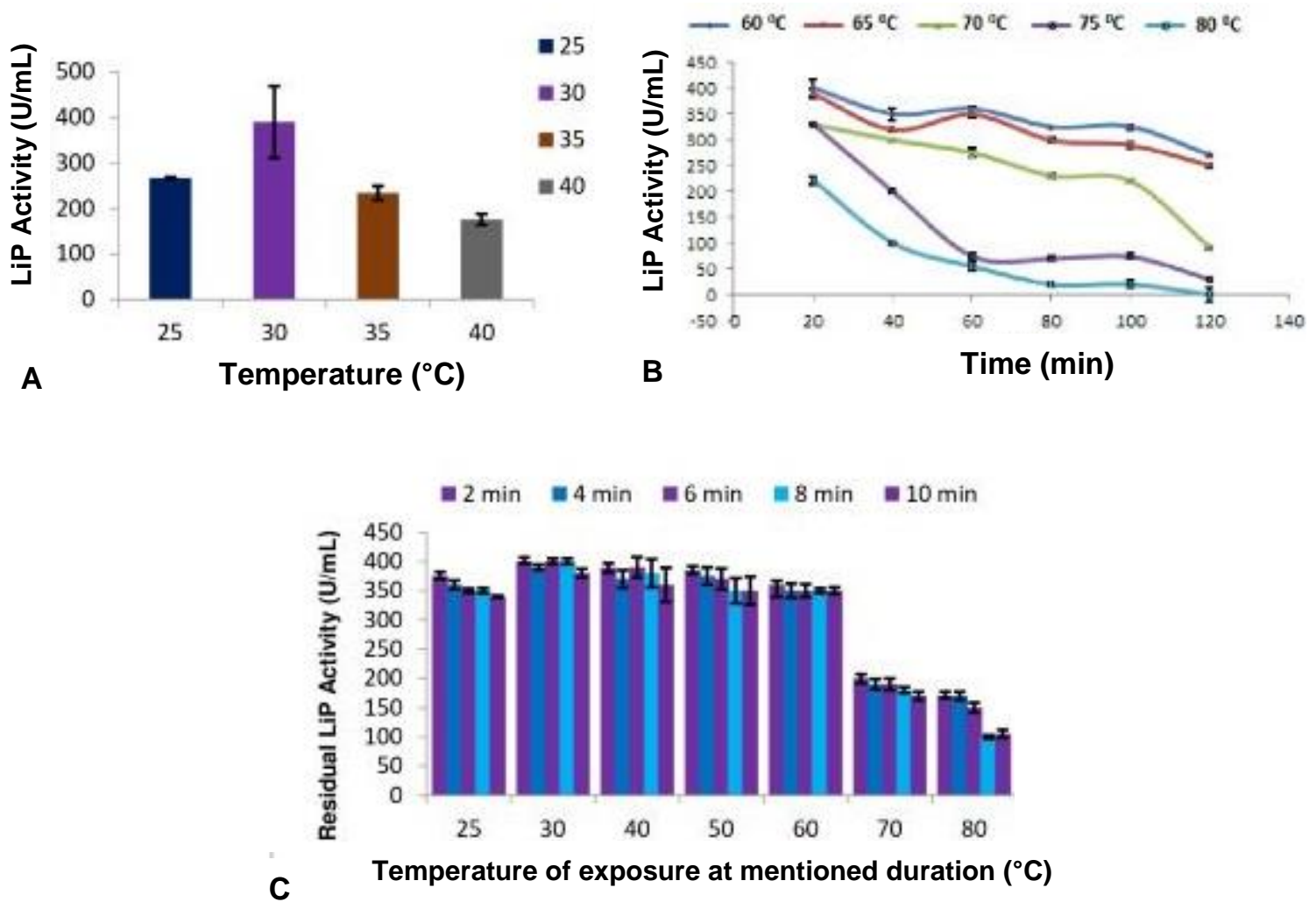

Fig. 6. (A) Temperature optima of the purified LiP; (B) temperature tolerance of the purified LiP; and $(C)$ exposure at various temperatures for ten minutes showing thermostability of purified LiP 
The results clearly highlighted that the LiP produced by the immobilized $P$. chrysosporium was thermostable compared with the native enzyme produced in the submerged culture. This finding was similar to that of Asgher et al. (2012), who observed optimum temperatures of $60{ }^{\circ} \mathrm{C}$ and $80{ }^{\circ} \mathrm{C}$ for free and immobilized LiPs, respectively. Asgher et al. (2012) concluded that immobilization enhanced the activity and thermostability potential of the LiP remarkably and immobilized LiP remained stable over broad $\mathrm{pH}$ and temperature ranges compared with the free enzyme.

\section{Effect of the Activators and Inhibitors on the LiP Activity}

The stimulatory/inhibitory effects of different organic compounds (EDTA, Cysteine, ethanol, sodium azide, mercaptoethanol, and silver nitrate) and metal ions $\left(\mathrm{Cu}^{2+}\right.$, $\mathrm{Fe}^{2+}, \mathrm{Mn}^{2+}, \mathrm{Na}^{+}, \mathrm{Zn}^{2+}, \mathrm{Mg}^{2+}, \mathrm{Hg}^{2+}, \mathrm{Ca}^{2+}$, and $\mathrm{Ag}^{+}$) on purified LiP were investigated. The results showed that the LiP was greatly inhibited by Cysteine, sodium azide, mercaptoethanol, and silver nitrate, and it was activated by ethanol and EDTA (Fig. 7A). Among the metal ions used, $\mathrm{Ag}^{+}$and $\mathrm{Zn}^{+}$caused LiP inhibition to various extents, whereas $\mathrm{Cu}^{2+}, \mathrm{Mn}^{+}, \mathrm{Na}^{+}$, and $\mathrm{Fe}^{2+}$ were LiP activators at both concentrations (Fig. 7B). The ions $\mathrm{Mg}^{2+}$ and $\mathrm{Ca}^{2+}$ failed to have any effect on the LiP activity. Tuisel et al. (1991) also reported an inhibition of LiP activity by sodium azide. Asgher et al. (2012) reported the activity of a novel extra thermostable $\mathrm{LiP}$ was stimulated to various extents by $\mathrm{Cu}^{2+}, \mathrm{Mn}^{2+}$, and $\mathrm{Fe}^{2+}$, whereas Cysteine, EDTA, and $\mathrm{Ag}^{+}$had inhibitory effects.
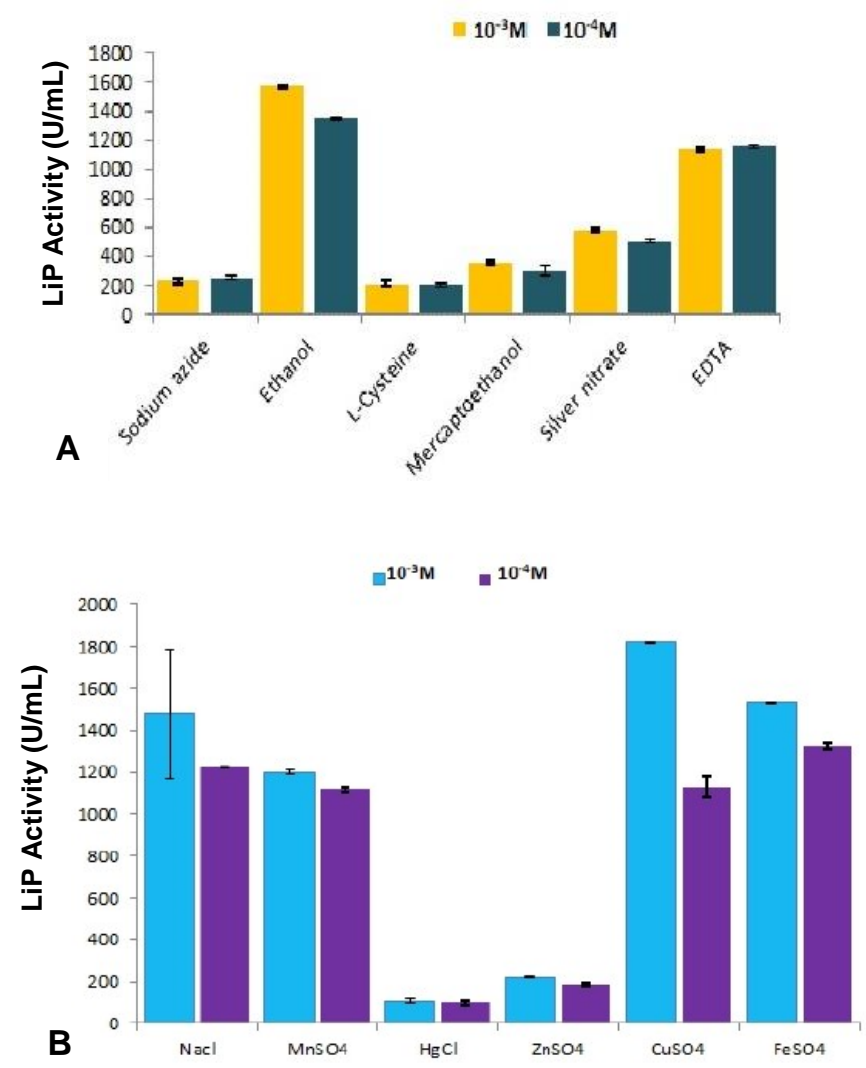

Fig. 7. Effect of the various $(A)$ activators/inhibitors and $(B)$ metal ions on the purified LiP 


\section{Effect of Various Substrates on the LiP Activity}

Lignin peroxidases can oxidize a number of aromatic phenolic compounds in a wide variety of applications. Amongst all of the mediator compounds tested, veratryl alcohol, which is known to act as an inducer, charge transfer mediator, or stabilizer in most white-rot fungi, caused an increase in the activity (Fig. 8). All of the other compounds tested failed to influence the LiP activity.

\section{Determination of the Kinetic Constants of the LiP}

The LiP from a liquid culture of Penicillium decumbens $\mathrm{P} 6$ exhibited $K_{\mathrm{m}}$ and $V_{\max }$ values of $0.565 \mathrm{mmol} / \mathrm{L}$ and $0.088 \mathrm{mmol} / \mathrm{mg}$ protein $\cdot \mathrm{min}$, respectively, using veratryl alcohol as the substrate (Yang et al. 2005), while the kinetic constants $K_{\mathrm{m}}$ and $V_{\max }$ reported for free and immobilized LiPs were $70 \mu \mathrm{M}$ and $56 \mu \mathrm{M}$, and $588 \mathrm{U} / \mathrm{mg}$ and $417 \mathrm{U} / \mathrm{mg}$, respectively (Asgher et al. 2012).

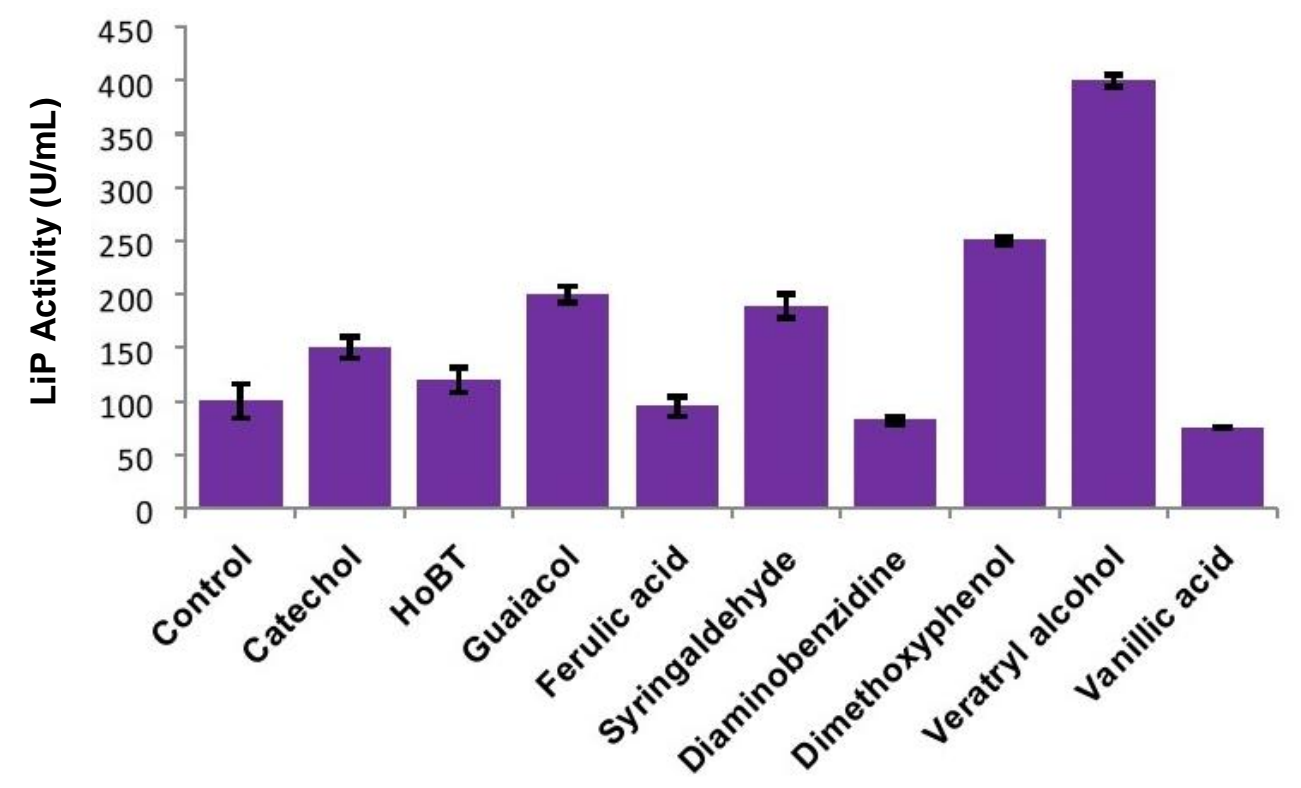

Fig. 8. Effect of the different substrates on the LiP activity

The highest LiP activity was obtained with veratryl alcohol, which exhibited a strong affinity for this substrate. Various concentrations of veratryl alcohol $(\mu \mathrm{M})$ ranging from $10 \mathrm{mM}$ to $140 \mathrm{mM}$ were plotted against the respective initial specific activities $(V)$ of the purified LiP obtained from immobilized P. chrysosporium. A Lineweaver-Burk reciprocal plot (Fig. 9A) was constructed. The Michalis-Menten kinetics yielded a hyperbolic curve (Fig. 9B). The $K_{\mathrm{m}}$ and $V_{\max }$ values of the purified LiP were $65 \mu \mathrm{M}$ and $142.86 \mu \mathrm{mol}$, respectively, which indicated that the enhanced substrate affinity and catalytic efficiency of the LiP was obtained through immobilization on the PUF cubes. 

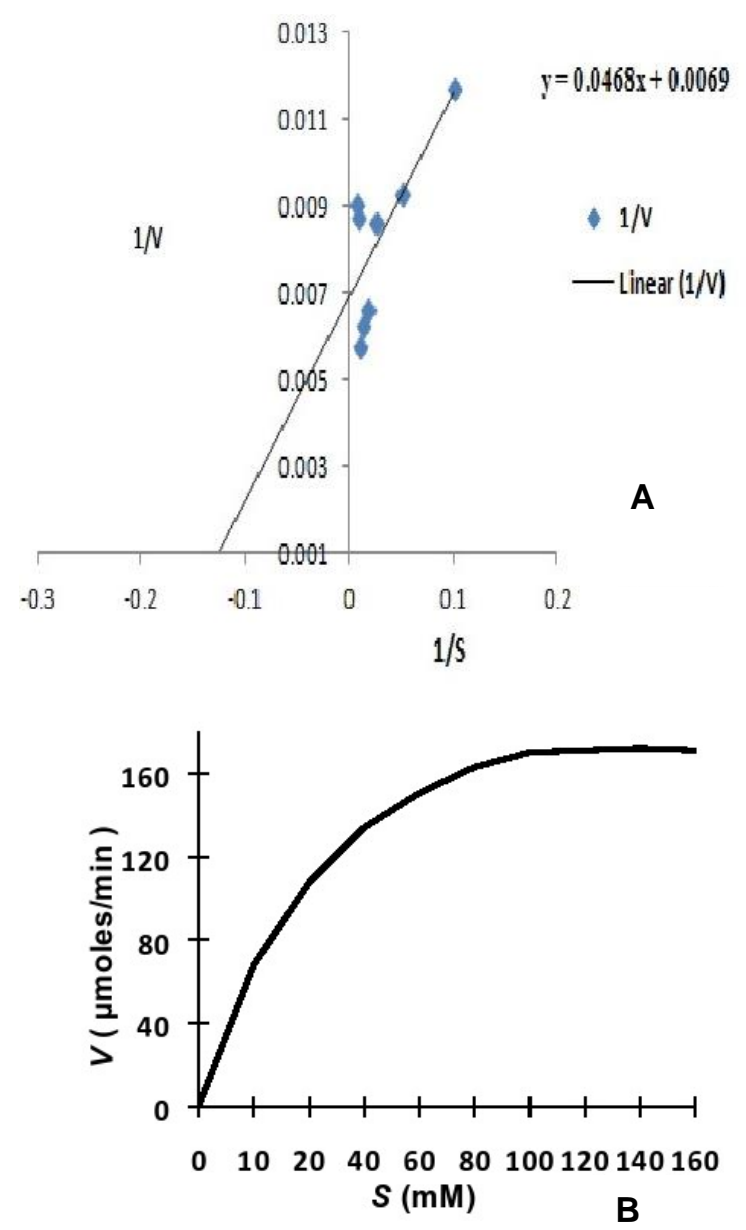

Fig. 9. (A) Lineweaver-Burk plot and (B) Michaelis Menton plot for the purified LiP obtained from the immobilized $P$. chrysosporium

\section{Dye Decolorization Assays}

Lignin peroxidase catalyzes the oxidation of phenolic, non-phenolic, and polycyclic aromatic hydrocarbon compounds, as well as a variety of recalcitrant aromatic compounds. Decolorization of synthetic dyes has also been reported. Alam et al. (2009) observed a $40 \%$ removal of methylene blue after the addition of approximately $0.5 \mathrm{U} / \mathrm{mL}$ LiP from P. chrysosporium. Color removal rates of $18 \%, 35 \%$, and $69 \%$ for Remazol Brilliant Blue Reactif $\left(\lambda_{\max }=592 \mathrm{~nm}\right.$; and $\left.25 \mathrm{mg} / \mathrm{L}\right)$, Acid Blue $158\left(\lambda_{\max }=610 \mathrm{~nm}\right.$, and $25 \mathrm{mg} / \mathrm{L})$, and Cibacet Brilliant Blue BG $\left(\lambda_{\max }=630 \mathrm{~nm}\right)$, respectively, after a 1-h treatment by LiP from Streptomyces griseosporeus SN9 were reported by Rekik et al. (2015). Shaheen et al. (2017) recorded an $80 \%$ to $93 \%$ decolorization of Sandal reactive dyes by Ganoderma lucidum IBL-05 LiP entrapped in Ca-alginate beads. Ollikka et al. (1993) investigated the ability of some LiPs from P. chrysosporium to decolorize azo, triphenyl methane, heterocyclic, and polymeric dyes. The capability of LiP to decolorize these dyes in the presence of veratryl alcohol as a mediator was confirmed. Cripps et al. (1990) did not observe decolorization of Congo red at a $\mathrm{pH}$ of 4.5 with crude LiP from a nitrogen-limited culture of $P$. chrysosporium.

Purified LiP obtained from immobilized P. chrysosporium completely (100\%) decolorized bromo phenyl blue, bromothymol blue and bromocresol green (Table 3) showing increased dye decolorization efficiency. The $96 \%$ degradation obtained with 
phenol red and $72 \%$ with congo red, also reflected a $56 \%$ and $44 \%$ enhancement respectively, in comparison to the degradation efficiency of the crude enzyme (Table 3), even without the addition of a mediator.

Table 3. Dye Decolorization Efficiency of the Crude and Purified LiP Obtained from the Immobilized $P$. chrysosporium

\begin{tabular}{|c|c|c|c|c|}
\hline \multirow{2}{*}{ Compound } & \multirow{2}{*}{$\boldsymbol{\lambda}_{\max }(\mathbf{n m})$} & \multicolumn{2}{|c|}{ Degradation (\%) } & \multirow{2}{*}{ Increase (\%) } \\
\cline { 3 - 4 } & & Crude LiP & Purified LiP & \\
\hline Bromophenyl blue & 598 & 53 & 100 & 47 \\
\hline Bromothymol blue & 616 & 62 & 100 & 38 \\
\hline Bromocresol green & 423 & 60 & 100 & 40 \\
\hline Phenol red & 443 & 40 & 96 & 56 \\
\hline Congo red & 497 & 28 & 72 & 44 \\
\hline
\end{tabular}

\section{Deconstruction of Lignin in the Crop Residues and in vitro Incubations}

Crop residues are refractory in nature for most solutions and enzymes because of their highly lignified cell walls linked to both hemicellulose and cellulose that form a physical seal around the latter two compounds, which creates an impenetrable barrier. Fungal treatments of fibrous agricultural by-products have a positive effect on the chemical composition. This has proven them to have a high potential to improve the nutritive value of highly lignified ruminant feeds (Tuyen et al. 2013). During degradation, this hemicellulose lignin matrix is primarily attacked by white-rot fungi (Martínez et al. 2005), which causes a change in the cell wall structure because of delignification and makes the cell contents easily accessible.

However, there is a dearth of studies on the effect of ligninolytic enzyme treatment on straw for ruminants. Rodrigues et al. (2008) extracted enzymes from the white-rot fungi T. versicolor (TV1 and TV2), Bjerkandera adusta, and Fomes fomentarius to evaluate their in vitro potential and increase the degradation of cell wall components of wheat straw. 
Table 4. Changes Obtained in the Fiber Fractions of the Straws upon Treatment with the Purified LiP(T1) Compared with the Untreated Control Straw(C)

\begin{tabular}{|c|c|c|c|c|c|c|}
\hline \multirow{2}{*}{ Straw } & \multirow{2}{*}{ Treatment } & \multicolumn{5}{|c|}{ \% Dry Matter Basis } \\
\cline { 2 - 7 } & & Dry Matter & ADF & NDF & ADL & IVDMD \\
\hline \multirow{3}{*}{ FM } & $\mathrm{C}$ & $95.85 \pm 3.14$ & $39.19 \pm 0.36$ & $78.18 \pm 0.61$ & $6.98 \pm 0.06$ & $40.00 \pm 3.65$ \\
\cline { 2 - 7 } & $\mathrm{T} 1$ & $93.87 \pm 8.76^{*}$ & $34.15 \pm 1.62^{* *}$ & $63.16 \pm 0.223^{* *}$ & $5.72 \pm 0.07^{*}$ & $58.24 \pm 1.06^{* *}$ \\
\hline \multirow{2}{*}{ LM } & $\mathrm{C}$ & $95.82 \pm 2.82$ & $49.19 \pm 0.36$ & $79.94 \pm 0.07$ & $6.48 \pm 0.16$ & $41.83 \pm 1.94$ \\
\cline { 2 - 7 } & $\mathrm{T} 1$ & $94.03 \pm 1.88$ & $31.08 \pm 0.12^{* *}$ & $74.49 \pm 6.20^{*}$ & $5.05 \pm 0.21^{*}$ & $54.15 \pm 1.78^{* *}$ \\
\hline \multirow{2}{*}{ BA } & $\mathrm{C}$ & $96.87 \pm 3.72$ & $46.13 \pm 0.66$ & $80.61 \pm 0.08$ & $6.91 \pm 0.02$ & $44.92 \pm 3.00$ \\
\cline { 2 - 7 } & $\mathrm{T} 1$ & $95.02 \pm 3.21$ & $45.75 \pm 1.60^{*}$ & $77.03 \pm 0.20^{* *}$ & $4.87 \pm 0.04^{* *}$ & $64.56 \pm 4.22^{* *}$ \\
\hline \multirow{2}{*}{ BRM } & $\mathrm{C}$ & $94.02 \pm 3.03$ & $48.89 \pm 0.75$ & $81.58 \pm 0.01$ & $6.9 \pm 0.09$ & $43.82 \pm 1.13$ \\
\cline { 2 - 7 } & $\mathrm{T} 1$ & $92.11 \pm 1.94^{*}$ & $45.11 \pm 0.28^{*}$ & $69.10 \pm 1.56^{* *}$ & $5.49 \pm 0.42^{*}$ & $64.69 \pm 2.08^{* *}$ \\
\hline \multirow{2}{*}{ MS } & $\mathrm{C}$ & $96.43 \pm 2.92$ & $49.56 \pm 0.90$ & $80.07 \pm 0.24$ & $6.23 \pm 0.15$ & $42.64 \pm 3.22$ \\
\cline { 2 - 7 } & $\mathrm{T} 1$ & $94.23 \pm 2.28^{*}$ & $40 \pm 1.05^{* *}$ & $73.65 \pm 0.64^{*}$ & $5.71 \pm 0.22^{*}$ & $62.57 \pm 3.02^{* *}$ \\
\hline \multirow{2}{*}{ JR } & $\mathrm{C}$ & $96.49 \pm 1.92$ & $46.69 \pm 0.11$ & $80.66 \pm 0.64$ & $7.00 \pm 0.44$ & $43.93 \pm 1.56$ \\
\cline { 2 - 7 } & $\mathrm{T} 1$ & $95.00 \pm 3.20$ & $41.57 \pm 0.38^{* *}$ & $72.02 \pm 1.04^{*}$ & $4.13 \pm 5.85^{* *}$ & $57.20 \pm 2.01^{* *}$ \\
\hline \multirow{2}{*}{ PS } & $\mathrm{C}$ & $95.32 \pm 3.10$ & $49.19 \pm 1.09$ & $81.58 \pm 0.71$ & $8.28 \pm 0.21$ & $41.86 \pm 3.96$ \\
\cline { 2 - 7 } & $\mathrm{T} 1$ & $94.81 \pm 2.01$ & $46.84 \pm 1.98^{*}$ & $66.05 \pm 2.76^{* *}$ & $5.62 \pm 0.01^{* *}$ & $58.50 \pm 3.25^{* *}$ \\
\hline \multirow{2}{*}{ FXM } & $\mathrm{C}$ & $96.31 \pm 1.97$ & $48.28 \pm 0.46$ & $81.40 \pm 0.59$ & $7.80 \pm 0.51$ & $43.31 \pm 0.94$ \\
\cline { 2 - 7 } & $\mathrm{T} 1$ & $95.11 \pm 3.80$ & $45.12 \pm 0.63^{*}$ & $69.50 \pm 0.71^{* *}$ & $6.36 \pm 0.03^{*}$ & $63.43 \pm 1.16^{* *}$ \\
\hline \multirow{2}{*}{ PRM } & $\mathrm{C}$ & $96.15 \pm 1.86$ & $49.83 \pm 0.13$ & $82.38 \pm 0.06$ & $6.78 \pm 0.12$ & $39.29 \pm 0.88$ \\
\cline { 2 - 7 } & $\mathrm{T} 1$ & $95.10 \pm 3.11$ & $38.44 \pm 0.18^{* *}$ & $66.69 \pm 1.89^{* *}$ & $5.68 \pm 0.06^{*}$ & $60.56 \pm 1.26^{* *}$ \\
\hline
\end{tabular}

C - untreated control straw; FM- Finger millet; LM- little millet; BA-bajra; BRM barnyard millet; PS- paddy straw; MS -maize stover ; JR jowar; FXM- foxtail millet and PRM proso millet; the values are the means \pm standard deviation of the samples estimated for three replicates; ${ }^{*} P \leq 0.05$; and ${ }^{* *} P \leq 0.01$ 
The results from the cell wall chemical composition analysis showed that the TV2 and BA enzyme extracts decreased the NDF concentration $(P<0.05)$ and that TV1 had a higher activity $(P<0.05)$ towards cellulose. There was an increase in the in vitro Neutral Detergent Fiber Digestibility (IVNDFD) caused by treatment of the wheat straw with enzyme extracts from $B$. adusta, TV1, and TV2, and reached a difference of $13 \%$ for TV2 $(P<0.05)$ versus the untreated control straw. Kumar et al. (2015) observed a decrease in the fiber content with an enhancement of the digestibility of straws treated with laccase obtained from Schizophyllum commune.

The purified enzyme extract of LiP utilized for treating nine different crop residues by spraying recorded a minimal loss in the dry matter ranging between 1 and 2 units (Table 4). Compared to untreated straws, treatment with LiP resulted in a decrease in NDF content, which ranged from the highest response of 18.02 units being recorded in ragi straw and a minimum decrease of 3.58 units in the BA. With regard to ADF content, little millet recorded the major decrease of 18.11 units, while the lowest decrease of 0.38 unit occurred in the case of BA.

Similarly, compared to untreated straws, the highest decrease in ADL contents after treatment with LiP ranged from 2.87 units obtained in JR, followed by 2.66 units in PS, and 2.04 units in BA. The in vitro digestibility (IVDMD) of all straws increased after treatment with purified LiP, (Table 4), the response in increase, ranging from a maximum of 21.27 units observed in PRM to a minimum of 12.32 units obtained in LM compared to untreated straws, confirming the potential of LiP in delignification of crop residues.

\section{CONCLUSIONS}

1. The results confirmed the secretion of LiP by the wild isolate of P. chrysosporium.

2. The LiP obtained from P. chrysosporium immobilized on PUF cubes elicited a higher thermostability, $\mathrm{pH}$ stability, and dye decolorization efficiency.

3. Treatment of nine crop residues with the purified LiP obtained from P. chrysosporium immobilized on PUF cubes had a statistically significant positive effect on their chemical composition and digestibility, which showed that LiP has a high potential to improve the nutritive value of highly lignified ruminant feeds.

\section{ACKNOWLEDGMENTS}

The financial assistance from the Department of Biotechnology, Ministry of Science and Technology, Government of India (Grant No. BT/PR11205/AAQ/1/589/2014) to perform the present research is gratefully acknowledged. The authors thank the Director of ICAR National Institute of Animal Nutrition and Physiology, Bangalore (India) for providing facilities to perform the research work.

\section{CONFLICTS OF INTEREST}

The authors declare that they have no conflicts of interest. 


\section{REFERENCES CITED}

AOAC (2005). Official Methods of Analysis of AOAC International, $18^{\text {th }}$ Edition, Association of Official Analytical Chemists (AOAC), Gaithersburg, MD.

Alam, M. Z., Mansor, M. F., and Jalal, K. C. A. (2009). "Optimization of decolorization of methylene blue by lignin peroxidase enzyme produced from sewage sludge with Phanerocheate chrysosporium," J. Hazard. Mater. 162(2-3), 708-715. DOI: 10.1016/j.jhazmat.2008.05.085

Arora, D. S., and Gill, P. K. (2001). "Comparison of two assay procedures for lignin peroxidase," Enzyme Microb. Tech. 28(7-8), 603-605. DOI: 10.1016/S01410229(01)00302-7

Arora, D. S., Sharma, R. K., and Chandra, P. (2011). "Biodelignification of wheat straw and its effect on in vitro digestibility and antioxidant properties," Int. Biodeter. Biodegr. 65(2), 352-358. DOI: 10.1016/j.ibiod.2010.12.009

Asgher, M., Iqbal, H. M. N., and Irshad, M. (2012). "Characterization of purified and xerogel immobilized novel lignin peroxidase produced from Trametes versicolor IBL-04 using solid state medium of corncobs," BMC Biotechnol. 12, 46. DOI: 10.1186/1472-6750-12-46

Cripps, C., Bumpus, J. A., and Aust, S. D. (1990). "Biodegradation of azo and heterocyclic dyes by Phanerochaete chrysosporium," Appl. Environ. Microb. 56, 1114-1118.

Datta, R., Kelkar, A., Baraniya, D., Molaei, A., Moulick, A., Meena, R. S., and Formanek, P. (2017). "Enzymatic degradation of lignin in soil: A review," Sustainability 9, 1163. DOI: 10.3390/su9071163

de Ory, I., Romero, L. E., and Cantero, D. (2004). "Optimization of immobilization conditions for vinegar production. Siran, wood chips and polyurethane foam as carriers for Acetobacter aceti," Process. Biochem. 39(5), 547-555. DOI: 10.1016/S0032-9592(03)00136-5

Fakoussa, R. M., and Hofrichter, M. (1999). "Biotechnology and microbiology of coal degradation," Appl. Microbiol. Biot. 52(1), 25-40. DOI: 10.1007/s002530051483

Glenn, J. K., Morgan, M. A., Mayfield, M. B., Kuwahara, M., and Gold, M. H. (1983). "An extracellular $\mathrm{H}_{2} \mathrm{O}_{2}$-requiring enzyme preparation involved in lignin biodegradation by the white rot basidiomycete Phanerochaete chrysosporium," Biochem. Biophy. Res. Co. 114(3), 1077-1083. DOI: 10.1016/0006-291X(83)90672-1

Goering, H. K., and Van Soest, P. J. (1970). Forage Fiber Analyses (Apparatus, Reagents, Procedures, and Some Applications) (Agricultural Handbook No. 379), U.S. Department of Agriculture Agricultural Research Service, Washington, D.C.

Hariharan, S., and Nambisan, P. (2013). "Optimization of lignin peroxidase, manganese peroxidase and lac production from Ganoderma lucidum under solid state fermentation of pineapple leaf," BioResources 8(1), 250-271. DOI: 10.15376/biores.8.1.250-271

Jeffries, T. W. (1994). "Biodegradation of lignin and hemicelluloses," in: Biochemistry of Microbial Degradation, C. Ratledge (ed.), Springer, Dordrecht, Netherlands, pp. 233277.

Kantelinen, A., Hatakka, A., and Viikari, A. (1989). "Production of lignin peroxidase and laccase by Phlebia radiata," Appl. Microbiol. Biot. 31(3), 234-239. DOI: 10.1007/BF00258401 
Kirk, T. K., and Farrell, R. L. (1987). 'Enzymatic 'combustion': The microbial degradation of lignin," Annu. Rev. Microbiol. 41, 465-505. DOI: 10.1146/annurev.mi.41.100187.002341

Kumar, V. P., Naik, C., and Sridhar, M. (2015). "Production, purification and characterization of novel laccase produced by Schizophyllum commune NI-07 with potential for delignification of crop residues," Appl. Biochem. Micro. + 51(4), 432441. DOI: $10.1134 / \mathrm{S} 0003683815040080$

Kuwahara, M., Glenn, J. K., Morgan, M. A., and Gold, M. H. (1984). “Separation and characterization of two extracellular $\mathrm{H}_{2} \mathrm{O}_{2}$-dependent oxidases from ligninolytic cultures of Phanerochaete chrysosporium," FEBS Lett. 169(2), 247-250. DOI: 10.1016/0014-5793(84)80327-0

Laemmli, U. K. (1970). "Cleavage of structural proteins during the assembly of the head of bacteriophage T4," Nature 227, 680-685.

Lowry, O. H., Rosebrough, N. J., Farr, A. L., and Randall, R. J. (1951). "Protein measurement with the Folin phenol reagent," J. Biol. Chem. 193(1), 267-275.

Martínez, A. T., Speranza, M., Ruiz-Dueñas, F. J., Ferreira, P., Camarero, S., Guillén, F., Martínez, M. J., Gutiérrez, A., and del Río, J. C. (2005). "Biodegradation of lignocellulosics: Microbial, chemical, and enzymatic aspects of the fungal attack of lignin," Int. Microbiol. 8(3), 195-204.

Moonmangmee, S., Kawabata, K., Tanaka, S., Toyama, H., Adachi, O., and Matsushita, K. (2002). "A novel polysaccharide involved in the pellicle formation of Acetobacter aceti," J. Biosci. Bioeng. 93(2), 192-200. DOI: 10.1016/S1389-1723(02)80013-5

Nakamura, Y., Sawada, T., Sungusia, M. G., Kobayashi, F., Kuwahara, M., and Ito, M. (1997). "Lignin peroxidase production by Phanerochaete chrysosporium immobilized on polyurethane foam," J. Chem. Eng. JPN. 30(1), 1-6. DOI: 10.1252/jcej.30.1

Niku-Paavola, M. L., Karhunen, E., Salola, P., and Raunio, V. (1988). "Ligninolytic enzymes of the white-rot fungus Phlebia radiata," Biochem. J. 254(3), 877-884.

Niku-Paavola, M. L., Raaska, L., and Itävaara, M. (1990). "Detection of white-rot fungi by a non-toxic stain," Mycol. Res. 94(1), 27-31. DOI: 10.1016/S09537562(09)81260-4

Ollikka, P., Alhonmäki, K., Leppänen, V.-M., Glumoff, T., Raijola, T., and Suominen, I. (1993). "Decolorization of azo, triphenyl methane, heterocyclic, and polymeric dyes by lignin peroxidase isoenzymes from Phanerochaete chrysosporium," Appl. Environ. Microb. 59(12), 4010-4016.

Piontek, K., Smith, A. T., and Blodig, W. (2001). "Lignin peroxidase structure and function," Biochem. Soc. T. 29(Part 2), 111-116.

Prasad, K. K., Mohan, S. V., Bhaskar, Y. V., Ramanaiah, S. V., Babu, V. L., Pati, B. R., and Sarma, P. N. (2005). "Laccase production using Pleurotus ostreatus 1804 immobilized on PUF cubes in batch and packed bed reactors: Influence of culture conditions," J Microbiol. 43(3), 301-307.

Rekik, H., Nadia, Z. J., Bejar, W., Kourdali, S., Belhoul, M., Hmidi, M., Benkiar, A., Badis, A., Sallem, N., Bejar, S., et al. (2015). "Characterization of a purified decolorizing detergent-stable peroxidase from Streptomyces griseosporeus SN9," Int. J. Biol. Macromol. 73, 253-263. DOI: 10.1016/j.ijbiomac.2014.11.021

Revankar, M. S., and Lele, S. S. (2006). "Enhanced production of laccase using a new isolate of white rot fungus WR-1," Process. Biochem. 41(3), 581-588. DOI: 10.1016/j.procbio.2005.07.019 
Rodrigues, M. A. M., Pinto, P., Bezerra, R. M. F., Dias, A. A., Guedes, C. V. M., Cardoso, V. M. G., Cone, J. W., Ferreira, L. M. M., Colaço, J., and Sequeira, C. A. (2008). "Effect of enzyme extracts isolated from white-rot fungi on chemical composition and in vitro digestibility of wheat straw," Anim. Feed Sci. Tech. 141(3-4), 326-338. DOI: 10.1016/j.anifeedsci.2007.06.015

Rogalski, J., Lundell, T., Leonowicz, A., and Hatakka, A. L. (1991). "Influence of aromatic compounds and lignin on production of lignolytic enzymes by Phlebia radiata," Phytochemistry 30(9), 2869-2872. DOI: 10.1016/S0031-9422(00)98215-3

Sarnklong, C., Cone, J. W., Pellikaan, W., and Hendriks, W. H. (2010). "Utilization of rice straw and different treatments to improve its feed value for ruminants: A review," Asian Austral. J. Anim. 23(5), 680-692. DOI: 10.5713/ajas.2010.80619

Schlosser, D., Grey, R., and Fritsche, W. (1997). "Patterns of ligninolytic enzymes in Trametes versicolor. Distribution of extra- and intracellular enzyme activities during cultivation of glucose, wheat straw and beech wood," Appl. Microbiol. Biot. 47(4), 412-418. DOI: 10.1007/s002530050949

Schmidt, O. (2006). Wood and Tree Fungi: Biology, Damage, Protection, and Use, Springer-Verlag, Berlin, Germany.

Schoemaker, H. E., and Piontek, K. (1996). "On the interaction of lignin peroxidase with lignin," Pure Appl. Chem. 68(11), 2089-2096. DOI: 10.1351/pac199668112089

Shaheen, R., Asgher, M., Hussain, F., and Bhatti, H. N. (2017). "Immobilized lignin peroxidase from Ganoderma lucidum IBL-05 with improved dye decolorization and cytotoxicity reduction properties," Int. J. Biol. Macromol. 103, 57-64. DOI: 10.1016/j.ijbiomac.2017.04.040

Sharma, R. K., and Arora, D. S. (2010a). "Changes in biochemical constituents of paddy straw during degradation by white rot fungi and its impact on in vitro digestibility," $J$. Appl. Microbiol. 109(2), 679-686. DOI: 10.1111/j.1365-2672.2010.04695.x

Sharma, R. K., and Arora, D. S. (2010b). "Production of lignocellulolytic enzymes and enhancement of in vitro digestibility during solid state fermentation of wheat straw by Phlebia floridensis," Bioresource Technol. 101, 9248-9253. DOI:

10.1016/j.biortech.2010.07.042

Sridhar, M., Bhatta, R., Dhali, A., Saravanan, M., Pradeep, V., and Thammaiah, V. (2015). "Effect of exogenous ligninolytic enzyme-treated ragi straw on DM intake, digestibility, rumen fermentation and rumen enzymes in sheep," Indian J. Anim. Sci. 85(9), 1012-1016.

Sugiura, M., Hirai, H., and Nishida, T. (2003). "Purification and characterization of a novel lignin peroxidase from white-rot fungus Phanerochaete sordida YK-624," FEMS Microbiol. Lett. 224(2), 285-290. DOI: 10.1016/S0378-1097(03)00447-6

Tien, M., and Kirk, T. K. (1988). "Lignin peroxidase of Phanerochaete chrysosporium," Method. Enzymol. 161, 238-249. DOI: 10.1016/0076-6879(88)61025-1

Tilley, J. M. A., and Terry, R. A. (1963). "A two-stage technique for the in vitro digestion of forage crops," J. Brit. Grassland Soc. 18(2), 104-111. DOI: 10.1111/j.13652494.1963.tb00335.x

Tuisel, H., Grover, T. A., Lancaster, J., Bumpus, J. A., and Aust, S .D. (1991). "Inhibition of lignin peroxidase $\mathrm{H} 2$ by sodium azide," Archives Biochem. Biophys. 288(2), 456-462. DOI: 10.1016/0003-9861(91)90220-D

Tuyen, D. V., Phuong, H. N., Cone, J. W., Baars, J. J. P., Sonnenberg, A. S. M., and Hendriks, W. H. (2013). "Effect of fungal treatments of fibrous agricultural byproducts on chemical composition and in vitro rumen fermentation and methane 
production," Bioresource Technol. 129, 256-263. DOI:

10.1016/j.biortech.2012.10.128

van Kuijk, S. J. A., Sonnenberg, A. S. M., Baars, J. J. P., Hendriks, W. H., and Cone, J. W. (2015). "Fungal treated lignocellulosic biomass as ruminant feed ingredient: A review," Biotechnol. Adv. 33(1), 191-202. DOI: 10.1016/j.biotechadv.2014.10.014

Van Soest, P. J., Robertson, J. B., and Lewis, B. A. (1991). "Methods for dietary fiber, neutral detergent fiber, and nonstarch polysaccharides in relation to animal nutrition," J. Dairy Sci. 74(10), 3583-3597. DOI: 10.3168/jds.S0022-0302(91)78551-2

Yang, J. S., Yuan, H. L., Wang, H. X., and Chen, W. X. (2005). "Purification and characterization of lignin peroxidases from Penicillium decumbens P6," World J. Microb. Biot. 21(4), 435-440. DOI: 10.1007/s11274-004-1876-2

Article submitted: February 13, 2019; Peer review completed: May 14, 2019; Revised version received: May 17, 2019; Accepted: May 20, 2019; Published: May 22, 2019. DOI: $10.15376 /$ biores.14.3.5380-5399 